\title{
UJI COBA PENGOLAHAN AIR WADUK MENJADI AIR MINUM DENGAN METODA KOAGULASI FILTRASI, DAN KLORINASI
}

\author{
Endiqaputri Dwi Damayanti, Suroso Bambang Eko Warno, Suprijandani
}

\begin{abstract}
Human needs water to meet the main needs for drinking water. In some areas in Indonesia, especially Dusun Karangwungu, Gresik shortage of water still frequently happens. The absence of water treatment in the reservoir exists in the area prompted me to conduct a research on physical, chemical, and microbiology of the water to be processed as drinking water.

This is a descriptive typed study and data were collected through the use of secondary data, laboratory examinations, and observations. After sampling, the sample was then given the treatment of coagulation, fitasion and chlorination. Laboratory results were then compared with Minister Regulation No. 492 of 2010.

The objective of this study was to proceed the reservoir water into drinking water in accordance with the Minister of Health Regulation number 492 year 2010 on Drinking Water Quality.

The results of the study showed reduction in 19 test parameters in accordance with Permenkes 492/2010. The results showed that the reservoir water can be used as raw material for drinking water by coagulation, filtration, and chlorination.

To society is expected to use reservoir water into drinking water to meet the needs. Further research for additional parameters in accordance with the Health Minister Regulation 492/2010 and Breakpoint chlorination and Chlor absorbance Power in chlorination process can be carried out.
\end{abstract}

Keywords : coagulation, filtration, chlorination of drinking water

\section{PENDAHULUAN}

Kemarau panjang di Kabupaten Gresik mengakibatkan 51 Desa kekeringan. Badan Penanggulangan Bencana Daerah (BPBD) Kabupaten Gresik mengirimkan 700 truk tangki untuk penyediaan air bersih. Daerah dengan kekurangan air diKabupaten Gresik khususnya di Kecamatan Balongpanggang, Benjeng, Cerme, Menganti dan Kedamean.

Karangwungu Merupakan salah satu Dusun di Desa Mojogede kecamatan Balongpanggang Kabupaten Gresik, Jawa Timur yang memiliki jumlah air tidak lebih dari kebutuhan masyarakatnya.

Keberadaan air waduk di Dusun Karangwungu Kabupaten Gresik merupakan potensi dari sumberdaya air yang memberikan manfaat bagi kelangsungan hidup jika dikelola dengan baik.

Waduk ini dibuat secara sederhana dengan menggali tanah lapang dengan sumber utamanya air hujan yang biasanya digunakan irigasi saja. Dengan begitu penggunaan waduk yang mampu menampung hujan menjadi sangat bermanfaat kala kemarau datang karena merupakan sarana utama guna mendapatkan air.

Air merupakan kebutuhan pokok bagi manusia, antara lain untuk keperluan rumah tangga taman kota, tempat rekreasi. industri, hotel, restoran, mall, serta keperluan pertanian maupun peternakan (Dinas Sumber Daya Air dan Pemukiman Provinsi Banten, 2015).

Dusun Karang Wungu Kabupaten Gresik, adalah satu wilayah yang mengalami defisit air bersih dan air minum karena pengelolaan sumber daya air yang kurang maksimal diperparah dengan populasi penduduk yang terus meningkat serta kualitas air permukaan mulai mengalami penurunan.

Kebutuhan yang pertama bagi terselenggaranya kesehatan yang baik adalah tersedianya air yang memadai dari segi kuantitas dan kualitasnya (Asmadi, Khayan dan Heru, 2011:1).

Kekuatiran utama dimana air dapat berfungsi sebagai media penularan penyakit memungkinkan organisme penyebab penyakit akan tersebar melalui penyediaan air. Ketersediaan air yang ada terlalu sedikit membuat kebersihan perorangan tidak mungkin dilakukan sebagaimana mestinya.

Kotaminasi mikroba memberi dampak negatif yang cukup besar bagi kesehatan sehingga pengendalian kontaminasi mikroba harus selalu menjadi perhatian utama (menurut WHO, 2004 dalam Apriningsih, 2005:5).

Untuk mengurangi timbulnya penyakit penting bagi kita sebagai manusia untuk tetap menjaga kelestariannya dengan melakukan pengelolaan air yang baik. Badan air yang dikelola dengan baik memiliki dampak positif yang sangat besar. (Asmadi, Khayan dan Heru, 2011:10)

Intervensi untuk memperbaiki kualitas air minum memberi keuntungan signifikan bagi kesehatan (menurut WHO, 2004 dalam Apriningsih, 2005:1). Peran teknologi pengolahan air menjadi sangat penting. (Budiyono dan Sumardiono, 2013:3) 
Penyediaan air minum untuk memenuhi kebutuhan masyarakat agar mendapatkan kehidupan yang sehat, bersih dan produktif. (Tri Joko, 2010:1) maka di buatlah unit pengolahan air dengan cara koagulasi, filtrasi, dan klorinasi, yang bertujuan untuk mengolah air waduk Karangwungu Kabupaten Gresik menjadi air minum (Sesuai dengan Permenkes 492/2010) yang memiliki kontribusi cukup besar dalam pemenuhan kebutuhan air minum di Dusun Karangwungu Kabupaten Gresik

\section{METODE PENELITIAN}

Penelitian ini termasuk pra eksperimen dengan rancangan One Group Pretest Postest disain. Penelitian ini dilakukan di Desa Karangbong RT.1 RW.1 No. 32 Kecamatan Gedangan, Sidoarjo pada bulan Januari - Juli 2016.

Sampel air diambil dari waduk di Dusun Karangwungu Desa Mojogede Kecamatan Balong panggang Kabupaten Gresik, untuk selanjutnya diperiksa secara Fisik, Kimia dan Mikrobiologi di laboratorium Terpadu Poltekkes Kemenkes Surabaya. Cara Sampling:

Pengambilan sampel dilaku kan dengan cara mengambil air waduk dusun Karangwungu kabupaten Gresik sebanyak 200 liter dengan menggunakan jirigen 20 liter, untuk selanjutnya dilakukan pengolahan .

Bahan dan alat : Batu Koral, Pasir Silica, Ijuk. Kalium Aluminium Sulfat, Arang, Kaporit, Jirigen plastic 20 liter, Tandon air 250 liter, pH meter, Beaker glass $1000 \mathrm{ml}$, Gelas ukur 1 liter, DAN Batang pengaduk

Intalasi Pengolahan Air Minum

Terdiri dari 5 (Lima) buah tandon air berkapasitas 250 liter, tinggi $120 \mathrm{~cm}$, diameter $80 \mathrm{~cm}$.
- Bak I (Satu), berfungsi sebagai penampung air baku dan bak pengendap secara gravitasi.

- Bak II (Dua), berfungsi sebagai bak koagulasi, (bak pengendap dengan menggunakan Kalium Aluminium Sulfat )

- Bak III (Tiga), berfungsi sebagai bak filtrasi

- Bak IV (Empat), berfungsi sebagai bak penampung filtrat dan klorinasi

- Bak V (Lima), merupakan bak penampung air hasil olahan yang siap di distribusikan guna memenuhi kebutuhan warga dusun Karang Wungu Kabupaten Gresik.

Pengolahan secara koagulasi, filtrasi dan klorinasi :

1. 200 liter sampel dimasukkan ke dalam bak pengendap pertama (I) untuk dilakukan pengendapan secara gravitasi.

2. Koloid / partikel dalam sampel yang tidak bisa mengendap secara gravitasi, dialirkan ke dalam bak pengendap ke II (Dua) dan ditambahkan Kalium Aluminium Sulfat, diaduk cepat selama 15 menit dan diaduk secara lambat selama 10 menit, diamkan selama 2-3 jam.

3. Endapan yang terbentuk dipisah kan dengan cara menyaring menggunakan filter yang berisikan kerikil / batu koral, pasir silica dan ijuk.

4. Filtrat dialirkan / ditambung kedalam bak ke (III) tiga, dan dilakukan klorinasi

5. Air hasil olahan diambil sebagian untuk dilakukan pemeriksaan ter hadap parameter Fisik, kimia, dan Mikrobiologi di laboratorium Terpadu Poltekkes Kemenkes Surabaya.

6. Hasil Uji Laboratorium yang didapatkan, dibandingkan dengan

Parameter Wajib secara Fisik Kimia, Mikrobiologi, dalam Permenkes 492/2010 tentang : Standar Air Minum.

Tabel 1

Hasil pemeriksaan parameter standar air minum

\begin{tabular}{cccccc}
\hline No & Parameter & Satuan & Batas Maksimum & \multicolumn{2}{c}{ Hasil } \\
\cline { 5 - 6 } & & & Pretest & Postest \\
\hline 1 & Kromium & Mg/liter & 0,05 & 0,7 & 0,009 \\
\hline 2 & Nitrit $\left(\mathrm{NO}_{2}{ }^{-}\right)$ & $\mathrm{Mg} /$ liter & 3 & 1 & 0,23 \\
\hline 3 & Nitrat $\left(\mathrm{NO}_{3}{ }^{-}\right)$ & $\mathrm{Mg} /$ liter & 50 & 4,286 & 1,331 \\
\hline 4 & Besi & $\mathrm{Mg} /$ liter & 0,3 & 0,069 & 0,031 \\
\hline 5 & Kesadahan & $\mathrm{Mg} /$ liter & 500 & 177,9 & 6.128 \\
\hline 6 & Klorida & $\mathrm{Mg} /$ liter & 250 & 0,109 & 0,198 \\
\hline 7 & Mangan & Mg/liter & 0,4 & 0,77 & 0,24 \\
\hline 8 & pH & $\neq$ & $6,5-8,5$ & 7,5 & 7 \\
\hline 9 & Zink $(\mathrm{Zn})$ & $\mathrm{Mg} /$ liter & 3 & 2,575 & 0,552 \\
\hline 10 & Sulfat & $\mathrm{Mg} /$ liter & 250 & 171,156 & 45,92 \\
\hline 11 & Tembaga & $\mathrm{Mg} /$ liter & 2 & 1,58 & 0,28 \\
\hline 12 & Bau & $\neq$ & Tidak Berbau & Tidak Berbau & Tidak Berbau \\
\hline 13 & Warna & $\mathrm{TCU}$ & 15 & 4 & 2 \\
\hline 14 & TDS & Mg/liter & 500 & 619 & 118 \\
\hline 15 & Kekeruhan & $\mathrm{NTU}$ & 5 & 25 & 1,088 \\
\hline 16 & Rasa & $\neq$ & Tidak Berasa & Tidak Berasa & Tidak Berasa \\
\hline 17 & Suhu & ${ }^{\circ} \mathrm{C}$ & Suhu Udara $\pm 3^{\circ} \mathrm{C}$ & $29,0{ }^{\circ} \mathrm{C}$ & $28,4^{\circ} \mathrm{C}$ \\
\hline 18 & MPN Coliform & MPN/100ml & 0 & 13 & 0 \\
\hline 19 & E.coli & Neg/Pos & Negatif & Negatif & Negatif \\
\hline
\end{tabular}




\section{HASIL DAN PEMBAHASAN}

Hasil :

Hasil penelitian air waduk Karangwungu Kabupaten Gresik, terhadap beberapa parameter Fisik, Kimia dan Mikrobiologi dapat di lihat pada tabel berikut :

Tabel 1 :

Hasil Pemeriksaan Laboratorium

Dari tabel tersebut diatas dapat diketahui bahwa, parameter MPN, TDS, Kekeruhan, Mangan dan Cromium dalam sampel air waduk Karangwungu Kabupaten Gresik, sebelum perlakuan didapatkan hasil lebih tinggi dari batas maksimal yang diperkenankan dalam Permenkes 492/2010.

Sedangkan hasil pemeriksaan laboratorium terhadap parameter tersebut setelah perlakuan telah memenuhi syarat air minum yang ditetapkan Permenkes 492/2010.

Pembahasan.

Menurunnya kadar zat pencemar didalam air waduk desa Karangwungu setelah proses pengolahan, bisa terjadi karena akibat / perlakuan terhadap air waduk tersebut melalui proses koagulasi, filtrasi dan klorinasi. Kadar $\mathrm{Cr}$ sebelum dilakukan perlakuan sebesar 0,7 mg/liter, melebihi nilai maksimal yang diperbolehkan. Setelah perlakuan nilai $\mathrm{Cr}^{-3}$ menurun $87,1 \%$ menjadi 0,009 $\mathrm{mg} / \mathrm{liter}$. ion $\mathrm{krom}\left(\mathrm{Cr}^{-3}\right)$ dalam air dapat berubah menjadi ion krom yang bervalensi enam / hexavalen $\left(\mathrm{Cr}^{-6}\right)$ yang bersifat toksik (racun), dan jika terakumulasi dalam tubuh dapat menyebabkan kanker. Penurunan kadar $\mathrm{Cr}$ berasal dari proses koagulasi, filtrasi juga klorinasi

Nitrat dan nitrit merupakan ion yang terbentuk secara alami sebagai bagian siklus nitrogen. Konsentrasi nitrat dalam air tanah dan air permukaan biasanya lebih rendah. Menurut Aaltje, Nitrat $\left(\mathrm{NO}_{3}{ }^{-}\right)$adalah ion - ion anorganik alami, bagian dari siklus nitrogen. Mikroba di air menguraikan zat yang mengandung nitrogen menjadi amonia, kemudian dioksidasikan menjadi Nitrit dan Nitrat. Oleh karena Nitrit $\left(\mathrm{NO}_{2}{ }^{-}\right)$dapat dengan mudah dioksidasikan menjadi Nitrat. Pencemaran sampah organik hewan dapat meningkatkan kadar nitrit maupun nitrat di dalam air. Pengkonsumsian air dengan kadar nitrat tinggi dapat menyebabkan gangguan kesehatan al: gondok, methemoglobinemia. Penurunan kadar nitrit dan nitrat berasal dari proses koagulasi, filtrasi juga klorinasi.

Kadar besi (Fe) setelah perlakuan mengalami penurunan sebesar $55 \%$ dari nilai sebelum pengolahan. Penurunan kadar Besi (Fe) berasal dari proses koagulasi, filtrasi juga klorinasi . Kadar Besi (Fe) sebelum perlakuan 0,069 mg / liter dan setelah perlakuan sebesar 0,031 $\mathrm{mg} / \mathrm{liter}$. Kadar besi yang melebihi $0,3 \mathrm{mg} /$ liter biasanya terjadi pada perairan anaerob. Hal ini disebabkan proses dekomposisi bahan organik yang berlebihan, sehingga jumlah karbondioksida $\left(\mathrm{CO}_{2}\right)$ relatif lebih banyak. Adanya kandungan Besi dalam air menyebabkan warna air menjadi kuning-coklat setelah beberapa saat kontak dengan udara.

Hasil pengujian kesadahan di laboratorium sebelum dilakukan perlakuan sebesar $177 \mathrm{mg} / \mathrm{lliter}$ dan setelah perlakuan $6,128 \mathrm{mg} /$ liter. Mengalami penurunan $96,5 \%$ sedangkan pada persyaratan nilai maksimum kesadahan sebesar 500 mg/liter. Sehinga dapat dikatakan nilai kesadahan memenuhi standar air minum. Nilai kesadahan menurun baik dengan koagulasi maupun filtrasi, koagulan menggumpalkan partikel - partikel dan zat organik yang tersuspensi, gumpalan tersebut turun mengendap ke bagian dasar.

Dalam jumlah kecil magnesium dibutuhkan oleh tubuh untuk pertumbuhan tulang, akan tetapi dalam jumlah besar dapat menyebabkan rasa mual.

Penurunan kadar Khlorida pada sampel diperoleh dari proses koagulasi, Khlorida terikat bersama koagulan dan membentuk flok flok kemudian ikut mengendap bersama koagulan saat proses pengendapan.

Kadar Mangan (Mn) sebelum pengolahan $0,77 \mathrm{mg} / \mathrm{liter}$, sedang kan nilai ambang batas sebesar 0,4 mg/liter. Setelah diberi perlakukan mendapatan kadar / nilai sebesar 0,24 mg/liter dengan prosentase penurunan $68,8 \%$. Penurunan terjadi karena Mangan ( $\mathrm{Mn}$ ) pada proses koagulasi terikat oleh koagulan dan membentuk flok / gumpalan besar yang mengendap.

Keberadaan ion hidrogen menggambarkan nilai $\mathrm{pH}$. Nilai $\mathrm{pH}$ sangat mempengaruhi proses biologi maupun kimiawi dalam perairan air waduk Karangwungu, selain itu nilai pH juga mempengaruhi toksisitas dari suatu seyawa kimia. $\mathrm{pH}$ dengan nilai rendah maupun tinggi meyebabkan kerusakan yang jelas terhadap kualitas air. Pengukuran $\mathrm{pH}$ dilakukan menggunakan kertas indikator $\mathrm{pH}$ universal, gabungan dari metil jingga, metil merah, bromtimol biru dan fenolftalein. $\mathrm{pH}$ air sebelum pengolahan 7,5 setelah pengolahan sebesar 7 atau netral. Walaupun tidak berdampak langsung pada kesehatan, $\mathrm{pH}$ merupakan salah satu parameter operasional mutu air yang paling penting pada setiap tahapan pegolahan air untuk memastikan proses pengolahan air dan desinfeksi air berjalan efektif.

Zink (Zn) dalam air mudah larut, apabila berikatan dengan Khlorida dan sulfat. Zink (Zn) diperlukan untuk membantu kerja enzim, Zink (Zn) pada air juga diperlukan dalam proses fotosintesis sebagai agen bagi transfer hidrogen dan berperan dalam pembentukan protein. Air dengan kadar Zink (Zn) tinggi akan terlihat berwarna dan membentuk lapisan yang berminyak saat di didihkan. Zink ( $\mathrm{Zn}$ ) bermanfaat bagi tubuh namun dalam dosis tertentu, kelebihan Zink ( $\mathrm{Zn}$ ) dalam air akan menimbulkan rasa yang tidak di inginkan. Nilai Zink (Zn) dalam sampel sebesar 2,575 mg/liter namun 
setelah perlakuan menurun sebesar $78,6 \%$ menjadi $0,552 \mathrm{mg} / \mathrm{liter}$. Hal ini disebabkan senyawa Zink $(\mathrm{Zn})$ terikat koagulan pada proses koagulasi dengan senyawa lain membentuk flok, selain itu Zink (Zn) juga menempel pada media filter saat filtrasi.

Kadar sulfat sebelum dilakukan perlakuan sebanyak 171,156 mg/liter dan setelah di diberikan perlakuan menjadi $45,92 \mathrm{mg} /$ liter dengan batas maksimum sebesar $250 \mathrm{mg} / \mathrm{liter}$. Presentase penurunan sebesar $73,2 \%$. Penurunan Sulfat terjadi ketika proses koagulasi maupun filtrasi. Sulfat terbentuk alami dalam sejumlah mineral, secara umum asupan sulfat dari air minum, ion sulfat merupakan salah satu yang banyak dijumpai pada air di alam. Di perairan, Sulfat berikatan dengan ion hidrogen dan oksigen, sulfat yang berikatan dengan logam alkali merupakan bentuk sulfat yang paling banyak ditemukan pada perairan. Reduksi anion sulfat menjadi hidrogen sulfida pada kondisi anaerob dalam proses dekomposisi bahan organik menimbulkan bau yang kurang sedap dan meningkatkan korosivitas logam.

Kadar tembaga $(\mathrm{Cu})$ setelah perlakuan $0,28 \mathrm{mg} /$ liter mengalami penurunan sebesar $82,3 \%$ dengan nilai sebelumnya $1,58 \mathrm{mg} / \mathrm{liter}$. Tembaga merupakan logam berat yang dijumpai pada perairan alami dan merupakan unsur yang essensial bagi tumbuhaan dan hewan. Penurunan terhadap nilai Tembaga diperoleh dari proses koagulasi dan filtrasi. Konsentrasi tinggi tembaga dapat menimbulkan rasa pahit dan mempengaruhi nilai kesadahan.

Warna hasil pemeriksaan sampel sebelum perlakuan 4 TCU dan sesudah perlakuan sebesar 2 TCU, dengan nilai ambang batas yang diperbolehkan menurut peryaratan standar kualitas air minum sebesar 15 TCU. warna dalam air biasanya disebabkan oleh keberadaan zat oraganik, warna juga sangat dipengaruhi oleh keberadaan zat besi (Fe) dan logam lain baik sebagai kekeruhan alami ataupun sebagai produk korosi. Penurunan terhadap nilai warna dipengaruhi proses filtrasi dan klorinasi, timbulnya warna karena adanya bahan organik, plankton, maupun ion seperti Besi (Fe) dan Mangan ( $\mathrm{Mn}$ ) yang mengalami proses oksidasi secara alami.

Hasil pemeriksaan pada sampel air waduk tadah hujan tidak berbau baik sebelum maupun setelah perlakuan. Air yang baik memiliki ciri tidak berbau bila dicium dari jauh maupun dari dekat, karena air yang berbau dapat berasal dari kontaminan kimia baik anorganik maupun organik atau proses biologis yang sedang mengalami dekomposisi (penguraian) oleh mikroorganisme air.

Nilai TDS sebelum perlakuan sebanyak 799 $\mathrm{mg} /$ liter, dengan kata lain tidak memenuhi standar air minum Permenkes 492/2010. setelah dilakukan perlakuan nilai TDS menurun menjadi $180 \mathrm{mg} / \mathrm{liter}$. Persetase penurunan TDS sebesar $77,5 \%$. Nilai TDS di dalam perairan dipengaruhi oleh banyak dan besarnya nilai ion seperti Kalsium (Ca), Besi (Fe), Nitrat $\left(\mathrm{NO}^{-3}\right)$, dan Sulfat $\left(\mathrm{SO}_{4}^{-2}\right)$ yang terdapat dari alam. Sehingga ketika nilai ion menurun berjalan lurus dengan penurunan TDS Hal ini terjadi karena padatan yang terlarut di dalam sampel terikat menjadi flok -flok Aluminum Sulfat yang lebih besar dan mengendap. Selain proses koagulasi, proses filtrasi juga mempengaruhi.

Nilai kekeruhan pada sampel sebelum perlakuan sebesar 25 NTU dan setelah perlakuan sebesar 1,088 NTU. Penurunan nilai kekeruhan terjadi pada proses pengendapan. Kekeruhan pada air disebabkan oleh adanya butiran koloid, semakin banyak kandungan koloid pada air maka air akan semakin keruh, kekeruhan air juga dapat ditimbulkan oleh adanya bahan yang terapung maupun terurai seperti bahan organik dan anorganik yang menghambat proses fotosintesis maupun penguraian di dalam air.

Air yang memiliki rasa menunjukkan bahwa kualitas air tersebut tidak baik. Misalnya air memiliki rasa asin, hal ini disebabkan oleh adanya garam tertetu yang larut dalam air. Pada persyaratan air diharuskan tidak memiliki rasa.

Nilai suhu pada sampel air saat proses sampling sebesar $24^{\circ} \mathrm{C}$ dengan suhu udara $30^{\circ} \mathrm{C}$ saat itu. Pada persyaratan kualitas air harus tidak lebih maupun kurang dari $3^{\circ} \mathrm{C}$ suhu pada udara disekitarnya. Air yang baik memiliki temperatur sama dengan temperatur udara yakni $20^{\circ} \mathrm{C}-26^{\circ} \mathrm{C}$, Jika air memiliki temperatur yang melebihi nilai normalnya artinya air tersebut mengandung zat zat tertentu yang mengeluarkn atau menyerap energi dalam air.

Koagulasi, filtrasi dan klorinasi.

Pada proses koagulasi tawas yang ditambahkan akan bereaksi dengan air dan melepaskan aluminium hidroksida yang dapat berikatan dengan zat pencemar dan membentuk zat baru / flok yang lebih besar dan mengendap. Selanjutnya dilakukan proses penyaringan.

Pada proses filtrasi, filter yang digunakan adalah batu koral dengan ketebalan $30 \mathrm{~cm}$, pasir silica dengan ketebalan $50 \mathrm{~cm}$, dan ketebalan ijuk $20 \mathrm{~cm}$, serta arang batok kelapa dengan ketebalan $10 \mathrm{~cm}$. Batu koral, pasir, dan ijuk sebagai saringan dapat menahan zat padat terlarut / melayang dengan cara menempel pada permukaan filter tersebut. Sedang kan arang aktif dapat menghilang kan warna dan bau. Semakain tinggi ketebalan filter yang digunakan maka filtrat yang diperoleh menjadi lebih baik, karena kotoran yang terdapat dalam air telah tersaring pada bahan filter.

Menurut Sukmatanti, Ani dan Mariana proses filtrasi juga menyaring flok-flok halus yang masih terdapat dalam air yang tidak terendapkan pada bak sedimentasi dan juga dapat menyaring bakteri ataupun mikrioorganisme yang terdapat dalam air. Kerikil dan ijuk berfungsi untuk menyaring partikel. Ijuk digunakan karena memiliki kelenturan sekaligus kepadatan sehingga mudah menyaring kotoran besar pada air. Pasir memproses pemisahan zat atau senyawa kimia yang tidak 
dibutuhkan. Semakin besar massa pasir yang digunakan mengakibat kan tingkat adsorpsi semakin tinggi (Penelitian Abrina Anggraini). Penurunan Nilai zat Tersusupensi dipengaruhi oleh komposisi batu koral, pasir silica, ijuk dan arang

Klorinasi merupakan salah satu proses desinfeksi dalam pengolahan air minum yang bertujuan untuk membunuh mikroorganismepatogen Klor menyebabkan kerusakan besar membran sel pada bakteri patogen seperti E.coli, sehingga bakteri tidak dapat berkembang biak (Nusa Idaman Said). Bakteri koliform dapat bekembang biak dan bertahan di dalam air, keberadaan bakteri koliform dapat digunakan sebagai indikator keefektifan peng olahan dan kebersihan air. Selain dapat membasmi organisme pathogen, klor dapat mengoksidasi besi (Fe) maupun mangan ( $\mathrm{Mn}$ ) dan memecah molekul organik seperti warna.

\section{DAFTAR PUSTAKA}

Ali, Aman, Idris. Pengaruh Variasi Dosis Koagulan Terhadap Perubahan Parameter Fisika Kimia Kualitas Air Baku (Studi Kasus : PDAM Kota Samarinda). http://id.portalgaruda.org/?ref=browse\&m od $=$ viewarticle\&article $=425731$. Diakses 21 April 2016.

Andrian, Fatmawati, dan Novel. Analisis Cemaran Bakteri Coliform dan Identifikasi Eschrichia Coli pada Air Isi Ulang dari Depot Di Kota Manado.

2014.http://ejournal.unsrat.ac.id/index.php /pharmacon/article/viewFile/5450/4957. Diakses pada 14 April 2016

Andrayani, Bherta Eka. Pengaruh Kombinasi Ketebalan Filter Pasir dan Arang Tempurung Kelapa Terhadap Penurunan Kadar Mangan Air Sumur.2013. http://eprints.ums.ac.id/26389/12/NASKAH _PUBLIKASI.pdf. Diakses 6 April 2016

Anggraini, Abrina S.P.

Penyisihan Kromium Pada Limbah Cair Dengan Menggunakan Unggun Filtrasi Pasir.

Diakses 20 April 2016.

Asmadi, Khayan, Kasjono. 2011. Teknologi Pengolahan Air Minum. Yogyakarta., Penerbit Gosyen Publishing.

Budiyono dan Sumardiono. 2013. Teknik Pengolahan Air. Yogyakarta., Penerbit Graha Ilmu

Efendi, Hefni. 2003. Telaah Kualitas Air. Yogyakarta., Penerbit PT Kansius (Anggota IKAPI)

Fardiaz, Srikandi. 1992. Polusi Air dan Udara. Yogyakarta., Penerbit Kanisius (Anggota IKAPI)

\section{KESIMPULAN}

Air waduk tadah hujan desa Karangwungu Kabupaten Gresik dapat diolah menjadi air minum sesuai dengan Peraturan Menteri Kesehatan 492 tahun 2010 dengan cara koagulasi, filtrasi, dan klorinasi guna memenuhi kebutuhan nya.

\section{SARAN}

Penggunaan bahan-bahan anorganik seperti batu koral, pasir silica, ijuk, arang dan tawas, perlu dimasyarakatkan, karena terbukti memiliki potensi yang cukup besar dalam menyaring bahan-bahan yang terkandung dalam badan air.

Pengolahan air badan air sebaiknya dilakukan secara kelompok besar atau dan bekerja sama dengan pemerintah daerah setempat mengingat sistem pengolahan dan kebutuhan atau volume air badan air yang akan diolah.

Mirdad dann Wahyono. Pengaruh Ketebala \& Diameter Media Saringan Pasir Lambat Untuk Mengolah Air PDAM Ditinjau dari Parameter E.Coli, Zat Organik, dan Detergen. http://digilib.its.ac.id/public/ITSUndergraduate-17350-Paper-pdf.pdf. Diakses 21 April 2016

Notoadmojo, Sukidjo. 2002. Metodologi Penelitian Kesehatan. Jakarta: PT Rineka Cipta, Anggota IKAPI.

Pangidoan. Anton, dan Syahroni. Pengolahan Air Bersih Dilingkungan Kampus Universitas Pasir Pengairan Dengan Sistem Up Flow. http://ejournal.upp.ac.id/index.php/mhsteknik/arti cle/view/209/217. 2013. Diakses pada 20 Maret 2016.

Peraturan Menteri Kesehatan Republik Indonesia Nomor 492/Menkes/Per/IV/2010 tentang Persyaratan Kualitas Air Mminum

Purnawijayanti, Hiasinta A. 2001. Sanitasi, Higiene, dan Keselamatan Kerja dalam Pengolahan Makanan. Yogyakarta., Penerbit Kanisius (Anggota IKAPI)

Sugiyono. 2015. Musim Kemarau Gresik Krisis Air Bersih.http://surabaya.tribunnews.com/20 15/08/02/musim-kemarau-gresik-krisis-airbersih. 18 Januari 2016.

Suyono. 2014. Pencemaran Kesehatan Lingkungan. Jakarta., Penerbit Buku Kedokteran EGC

Syarifah, Fitri. 2015. Beberapa Provinsi Di Indonesia Ini Sedang Krisis Air Bersih. http://health.liputan6.com/read/2303297/b eberapa-provinsi-di-indonesia-ini-sedangkrisis-air-bersih. 18 Januari 2016.

Apriningsih; Widyastuti, Palupi (Alih Bahasa), 2005. Pedoman Mutu Air Minum, Edisi 3. Penerbit Buku Kedokteran EGC. Cetakan 2011. 